\title{
CHEMICAL COMPOSITION OF Hypericum perforatum L. ESSENTIAL OIL
}

\author{
Aleksandra S. Đorđević*
}

(ORIGINAL SCIENTIFIC PAPER) UDC 66

Department of Chemistry, Faculty of Science and Mathematics, University of Niš, Niš, Serbia

The essential oil isolated from fresh aerial parts of Hypericum perforatum L. was analyzed by GC and GC/MS. One hundred and thirty four identified compounds accounted for $98.7 \%$ of the total oil. The main components of the oil were: germacrene D (18.6\%), (E)-caryophyllene $(11.2 \%)$, 2-methyloctane $(9.5 \%)$, $\alpha$-pinene $(6.5 \%)$, bicyclogermacrene $(5.0 \%)$ and $(E)-\beta$-ocimene $(4.6 \%)$. The volatile profile of $H$. perforatum was characterized by a large content of sesqiuterpenoids (57.7\%), especially sesquiterepene hydrocarbons $(48.7 \%)$. Monoterpenoids (22.4\%) also consisted mostly of hydrocarbons (21.4\%). Nonterpenoid compounds amounted to $18.1 \%$ of the total oil.
Keywords: Hypericum perforatum, Hypericaceae, essential oil composition.

\section{Introduction}

More than 480 species of the genus Hypericum L. (Hypericaceae) naturally occur in, or have been introduced to every continent except in Antarctica [1]. The plants of the genus Hypericum have been used as traditional medicinal plants all over the world [2], especially Hypericum perforatum (St. John's wort). Hypericum perforatum is a perennial, rhizomatous herb. This species is characterized by a very wide ecological amplitude and can grow under different environmental conditions. It is found in various types of oak forest, in thickets, meadows and pastures, forest clearings, burnt areas, etc. Both extracts and essential oils of Hypericum species have been shown to possess significant antiviral, wound healing, antioxidant and antimicrobial activities [3-10]. Some of these actions were attributed to the presence of phloroglucinols (antibacterial, wound healing, antimalarial and antidepressant activity), naphthodianthrones (antiviral and antidepressant activity), xanthones (antimicrobial, antiviral and antidepressant activity), tannins (antiviral, antimicrobial and antioxidant activity), flavonoids (antifungal, antioxidant and antidepressant activity) and volatile oils (antimicrobial activity) [11-14].

There are many studies on $H$. perforatum essential oil composition and they show a significant variation in volatile profile of this species. Germacrene D, a-pinene, $\beta$-caryophyllene, 2-methyloctane and n-nonane were among major components in $H$. perforatum essential oils reported by many authors [15-35].

The aim of this study was to perform a detailed compositional analysis of $H$. perforatum volatiles and compare the obtained results with previously published essential oil profiles of the mentioned species.

\section{Experimental}

\section{Plant material.}

Above-ground parts of $H$. perforatum in the flowering phase were collected in the region of southeastern Serbia in July 2008. Voucher specimens were deposited in the Herbarium of the Faculty of Science and Mathematics, University of Niš, under the acquisition number 7292.

Essential oil isolation.

Fresh aerial parts $(400 \mathrm{~g})$ of $H$. perforatum were subjected to hydrodistillation for $2.5 \mathrm{~h}$ using the original Clevenger-type apparatus and yielded $0.08 \%(\mathrm{w} / \mathrm{w})$ of the pale yellow essential oil. The obtained oil was separated, dried over anhydrous magnesium sulfate and immediately analyzed.

\section{Essential oil analyses.}

The chemical composition of the oil was investigated by GC and GC/MS. The GC/MS analyses (three repetitions) were carried out using a Hewlett-Packard 6890N gas chromatograph equipped with a fused silica capillary column HP-5MS (5\% phenylmethylsiloxane, $30 \mathrm{~m} \times 0.25 \mathrm{~mm}$, film thickness $0.25 \mu \mathrm{m}$, Agilent Technologies, USA) coupled with a 5975B mass selective detector from the same company. The injector and interface were operated at $250^{\circ} \mathrm{C}$ and $300^{\circ} \mathrm{C}$, respectively. The oven temperature was raised $70^{\circ}-290^{\circ} \mathrm{C}$ at a heating rate of $5^{\circ} \mathrm{C} / \mathrm{min}$ and then isothermally held for $10 \mathrm{~min}$. As a carrier gas, helium at $1.0 \mathrm{~mL} / \mathrm{min}$ was used. The sample, $1 \mu \mathrm{L}$ of oil solution in diethyl ether $(1: 100)$, was injected in a pulsed

\footnotetext{
*Author address: Aleksandra S. Đorđević, Department of Chemistry, Faculty of Science and Mathematics, University of Niš, Višegradska 33, 18000 Niš, Serbia

E-mail: sanjadj81@yahoo.com

The manuscript received: April, 30, 2015.

Paper accepted: May, 15, 2015
} 
split mode (the flow was $1.5 \mathrm{~mL} / \mathrm{min}$ for the first $0.5 \mathrm{~min}$ and then set to $1.0 \mathrm{~mL} / \mathrm{min}$ throughout the remainder of the analysis; split ratio $40: 1)$. MS (electron impact) conditions were as follows: ionization voltage of $70 \mathrm{eV}$, acquisition mass range $35-500$, scan time $0.32 \mathrm{~s}$. Oil constituents were identified by comparison of their linear retention indices (relative to n-alkanes [36] on the HP-5MS column) with literature values [37] and their mass spectra with those of authentic standards, as well as those from Wiley 6, NIST02, MassFinder 2.3, and a homemade MS library with the spectra corresponding to pure substances and components of known essential oils, and wherever possible, by co-injection with an authentic sample. GC (FID) analysis was carried out under the same experimental conditions using the same column as described for the GC/MS. The percentage composition of the oil was computed from the GC peak areas without any corrections.

\section{Results and Discussion}

The results of the chemical analysis of $H$. perforatum essential oil by using GC and GC/MS methods are listed in Table 1. One hundred and thirtyfour components were identified, making $98.7 \%$ of total oil ingredients. The main components of $H$. perforatum oil were: germacrene D $(18.6 \%),(E)$-caryophyllene $(11.2 \%), 2$-methyloctane $(9.5 \%)$, a-pinene $(6.5 \%)$, bicyclogermacrene $(5.0 \%)$ and $(E)-\beta$-ocimene $(4.6 \%)$. The oil was characterized by the fraction of terpenoid compounds amounting to $80.1 \%$ (Table 1). Within this fraction, sesquiterpenoids $(57.7 \%)$ were mostly made of hydrocarbons $(48.7 \%)$, whereas oxygenated derivatives were present with $9.0 \%$. Sesquiterpenoids were represented 2.5 times more than monoterpenoids $(22.4 \%)$, the latter consisting mostly of hydrocarbons $-21.4 \%$, while the oxygenated fraction was present only with $1.0 \%$. Monoterpenoids were dominated by the pinane structure compound type (10.1\%) and acyclic monoterpenes (7.2\%), while sesquiterpenoids consisted mainly of germacrane $(23.6 \%)$, caryophyllane $(12.8 \%)$ and cadinane $(12,6 \%)$ structure types. Non-terpenoid compounds amounted to $18.1 \%$ of the total oil. This compound class consisted mainly of alkanes (14.1\%): isoalkanes (10.7\%), n-alkanes (2.0\%) and anteiso-alkanes $(1,4 \%)$ and fatty acids and their derivatives (FAD) (3.8\%).

Table 1. Percentage composition of $H$. perforatum essential oil

\begin{tabular}{clcc}
\hline RI & Compound & Content [\%] & $\begin{array}{c}\text { Identification } \\
\text { method }\end{array}$ \\
\hline 764 & (Z)-2-Penten-1-ol & 0.1 & $\mathrm{a}, \mathrm{b}$ \\
765 & 3-Methyl-2-buten-1-ol (syn. prenol) & 0.1 & $\mathrm{a}, \mathrm{b}$ \\
778 & 3-Methyl-2-butenal (syn. prenal) & $\operatorname{tr}$ & $\mathrm{a}, \mathrm{b}$ \\
800 & Octane & $\operatorname{tr}$ & $\mathrm{a}, \mathrm{b}, \mathrm{c}$ \\
832 & 2-Methylbutanoic acid & $\operatorname{tr}$ & $\mathrm{a}, \mathrm{b}, \mathrm{c}$ \\
847 & (E)-Hex-3-en-1-ol & $\operatorname{tr}$ & $\mathrm{a}, \mathrm{b}$ \\
851 & (Z)-Hex-3-en-1-ol & 1.2 & $\mathrm{a}, \mathrm{b}$ \\
859 & 2-Methyloctane & 9.5 & $\mathrm{a}, \mathrm{b}$ \\
862 & Hexan-1-ol & $\operatorname{tr}$ & $\mathrm{a}, \mathrm{b}$ \\
867 & 3-Methyloctane & $\operatorname{tr}$ & $\mathrm{a}, \mathrm{b}$ \\
900 & Nonane & 1.5 & $\mathrm{a}, \mathrm{b}, \mathrm{c}$ \\
924 & a-Thujene & 0.7 & $\mathrm{a}, \mathrm{b}$
\end{tabular}

\begin{tabular}{|c|c|}
\hline 932 & $\alpha$-Pinene \\
\hline 952 & Camphene \\
\hline 954 & 2-Methylnonane \\
\hline 959 & Benzaldehyde \\
\hline 965 & 3-Methylnonane \\
\hline 972 & Sabinene \\
\hline 974 & $\beta$-Pinene \\
\hline 981 & 6-Methyl-5-hepten-2-on \\
\hline 988 & $\beta$-Myrcene \\
\hline 1000 & Decane \\
\hline 1001 & (E)-Hex-3-enyl acetate \\
\hline 1005 & a-Phellandrene \\
\hline 1116 & $\alpha$-Terpinene \\
\hline 1023 & p-Cymene \\
\hline 1027 & Limonene \\
\hline 1027 & $\beta$-Phellandrene \\
\hline 1030 & 1,8-Cineole \\
\hline 1032 & $(Z)-\beta$-Ocimene \\
\hline 1044 & $(E)-\beta$-Ocimene \\
\hline 1056 & $\mathrm{y}$-Terpinene \\
\hline 1057 & 2-Methyldecane \\
\hline 1063 & 3-Methyldecane \\
\hline 1068 & cis-Linalool oxide (furanoid) \\
\hline 1087 & Terpinolene \\
\hline 1100 & Undecane \\
\hline 1102 & Linalool \\
\hline 1102 & Nonanal \\
\hline 1103 & 2-Methylbutyl-3-methylbutanoate \\
\hline 1135 & cis-p-Ment-2-en-1-ol \\
\hline 1137 & trans-p-Ment-2-en-1-ol \\
\hline 1145 & Camfor \\
\hline 1165 & $(E)$-2-Nonen-1-ol \\
\hline 1177 & Terpinen-4-ol \\
\hline 1181 & (E)-3-Hexenylbutanoate \\
\hline 1183 & p-Cymen-8-ol \\
\hline 1191 & $\alpha$-Terpineole \\
\hline 1203 & Decanal \\
\hline 1229 & (Z)-Hex-3-enyl-2-methylbutanoate \\
\hline 1232 & (Z)-Hex-3-enyl-3-methylbutanoate \\
\hline 1239 & Thymol methyl ether (syn. Methyl-thymol) \\
\hline 1263 & 2-Methyldodecane \\
\hline 1278 & $(E)$-2-Decen-1-ol \\
\hline 1288 & Undecan-2-one \\
\hline 1300 & Tridecane \\
\hline 1327 & Isobutyl benzoate \\
\hline 1336 & Bicycloelemene \\
\hline 1350 & $\alpha$-Cubebene \\
\hline 1353 & a-Longipinene \\
\hline 1361 & $(E)$-2-Undecenal \\
\hline 1367 & $(E)$-2-Undecen-1-ol \\
\hline 1373 & $\alpha$-Ylangene \\
\hline 1374 & a-Copaene \\
\hline 1381 & 2-epi-a-Funebrene \\
\hline 1384 & Unidentified \\
\hline 1387 & $\beta$-Bourbonene \\
\hline 1391 & $\beta$-Cubebene \\
\hline 1396 & $\beta$-Elemene \\
\hline 1397 & (Z)-Jasmone \\
\hline 1406 & Dodecanal \\
\hline 1411 & $\alpha$-Gurjunene \\
\hline 1414 & 2-epi- $\beta$-Funebrene \\
\hline 1422 & (E)-Caryophyllene \\
\hline 1424 & $\beta$-Cedrene \\
\hline 1431 & $\beta$-Copaene \\
\hline 1435 & Isoamyl benzoate \\
\hline 1437 & Aromadendrene \\
\hline 1440 & $(Z)-\beta$-Farnesene \\
\hline
\end{tabular}

\begin{tabular}{|c|c|}
\hline 6.5 & $a, b, c$ \\
\hline $\operatorname{tr}$ & $a, b$ \\
\hline $\operatorname{tr}$ & $a, b$ \\
\hline $\operatorname{tr}$ & $a, b, c$ \\
\hline 1.4 & $a, b$ \\
\hline 0.9 & $a, b$ \\
\hline 3.6 & $a, b, c$ \\
\hline $\operatorname{tr}$ & $a, b$ \\
\hline 1.1 & $a, b, c$ \\
\hline $\operatorname{tr}$ & $a, b, c$ \\
\hline $\operatorname{tr}$ & $a, b$ \\
\hline 0.1 & $a, b, c$ \\
\hline 0.4 & $a, b$ \\
\hline 0.1 & $a, b, c$ \\
\hline 0.4 & $a, b, c$ \\
\hline 0.4 & $a, b$ \\
\hline $\operatorname{tr}$ & $a, b$ \\
\hline 1.5 & $a, b$ \\
\hline 4.6 & $a, b$ \\
\hline 0.9 & $a, b, c$ \\
\hline 1.0 & $a, b$ \\
\hline $\operatorname{tr}$ & $a, b$ \\
\hline $\operatorname{tr}$ & $a, b$ \\
\hline 0.2 & $a, b$ \\
\hline 0.5 & $a, b, c$ \\
\hline $\operatorname{tr}$ & $a, b, c$ \\
\hline 0.1 & $a, b$ \\
\hline $\operatorname{tr}$ & $a, b$ \\
\hline tr & $a, b$ \\
\hline 0.1 & $a, b$ \\
\hline $\operatorname{tr}$ & $a, b, c$ \\
\hline 0.2 & $a, b$ \\
\hline 0.6 & $a, b, c$ \\
\hline $\operatorname{tr}$ & $a, b$ \\
\hline $\operatorname{tr}$ & $a, b$ \\
\hline 0.3 & $a, b, c$ \\
\hline 0.1 & $a, b, c$ \\
\hline $\operatorname{tr}$ & $a, b$ \\
\hline 0.1 & $a, b$ \\
\hline tr & $a, b$ \\
\hline 0.2 & $a, b$ \\
\hline $\operatorname{tr}$ & $a, b$ \\
\hline $\operatorname{tr}$ & $a, b$ \\
\hline $\operatorname{tr}$ & $a, b, c$ \\
\hline $\operatorname{tr}$ & $a, b, c$ \\
\hline 0.1 & $a, b$ \\
\hline 0.1 & $a, b$ \\
\hline $\operatorname{tr}$ & $a, b$ \\
\hline $\operatorname{tr}$ & $a, b$ \\
\hline 0.1 & $a, b$ \\
\hline 0.1 & $a, b$ \\
\hline 0.3 & $a, b$ \\
\hline $\operatorname{tr}$ & $a, b$ \\
\hline 0.1 & \\
\hline 0.2 & $a, b$ \\
\hline 0.2 & $a, b$ \\
\hline 0.1 & $a, b$ \\
\hline $\operatorname{tr}$ & $a, b$ \\
\hline $\operatorname{tr}$ & $a, b$ \\
\hline $\operatorname{tr}$ & $a, b$ \\
\hline 1.0 & $a, b$ \\
\hline 11.2 & $a, b, c$ \\
\hline $\operatorname{tr}$ & $a, b$ \\
\hline 0.4 & $a, b$ \\
\hline 0.3 & $a, b, c$ \\
\hline 0.3 & $a, b$ \\
\hline $\operatorname{tr}$ & $a, b$ \\
\hline
\end{tabular}




\begin{tabular}{|c|c|c|c|}
\hline 1446 & cis-Muurola-3,5-diene & 0.2 & $a, b$ \\
\hline 1450 & Geranyl acetone & $\operatorname{tr}$ & $a, b$ \\
\hline 1452 & trans-Muurola-3,5-diene & 0.1 & $a, b$ \\
\hline 1456 & $\alpha$-Humulene & $\operatorname{tr}$ & $a, b, c$ \\
\hline 1457 & $(E)-\beta$-Farnesene & 1.5 & $a, b$ \\
\hline 1463 & allo-Aromadendrene & $\operatorname{tr}$ & $a, b$ \\
\hline 1469 & $\beta$-Acoradiene & 0.2 & $a, b$ \\
\hline 1471 & Dodecan-1-ol & 0.8 & $a, b$ \\
\hline 1472 & cis-Muurola-4(14),5-diene & 0.6 & $a, b$ \\
\hline 1475 & trans-Cadina-1(6),4-diene & 0.2 & $a, b$ \\
\hline 1481 & $\mathrm{Y}$-Muurolene & 1.4 & $a, b$ \\
\hline 1484 & Germacrene D & 18.6 & $a, b$ \\
\hline 1492 & $(Z, E)$ - $\alpha$-Farnesene & 1.2 & $a, b$ \\
\hline 1494 & cis-Cadina-1,4-diene & 0.6 & $a, b$ \\
\hline 1497 & trans-Muurola-4(14),5-dien & $\operatorname{tr}$ & $a, b$ \\
\hline 1501 & Bicyclogermacrene & 5.0 & $a, b$ \\
\hline 1501 & a-Muurolene & $\operatorname{tr}$ & $a, b$ \\
\hline 1506 & $(E, E)$ - $\alpha$-Farnesene & 0.9 & $a, b$ \\
\hline 1508 & $\delta$-Amorphene & 0.3 & $a, b$ \\
\hline 1509 & $\beta$-Curcumene & $\operatorname{tr}$ & $a, b$ \\
\hline 1516 & Y-Cadinene & 1.0 & $a, b$ \\
\hline 1526 & $\delta$-Cadinene & 2.3 & $a, b$ \\
\hline 1528 & Zonarene & 0.1 & $a, b$ \\
\hline 1534 & trans-Cadina-1,4-diene & 0.2 & $a, b$ \\
\hline 1539 & $\alpha$-Cadinene & 0.3 & $a, b$ \\
\hline 1545 & a-Calacorene & $\operatorname{tr}$ & $a, b$ \\
\hline 1567 & (E)-Nerolidol & 0.6 & $a, b$ \\
\hline 1569 & (Z)-Hex-3-enyl benzoate & 0.5 & $a, b$ \\
\hline 1580 & Spathulenol & 0.3 & $a, b, c$ \\
\hline 1586 & Caryophyllene oxide & 1.6 & $a, b, c$ \\
\hline 1604 & Viridiflorol & 0.4 & $a, b$ \\
\hline 1604 & Rosifoliol & 0.2 & $a, b$ \\
\hline 1610 & Ledol & $\operatorname{tr}$ & $a, b$ \\
\hline 1617 & 1,10-di-epi-Cubenol & 0.1 & $a, b$ \\
\hline 1619 & Humulene epoxide II & 0.1 & $a, b$ \\
\hline 1622 & Junenol & 0.2 & $a, b$ \\
\hline 1630 & 1-epi-Cubenol & 0.2 & $a, b$ \\
\hline 1633 & cis-Cadin-4-en-7-ol & 1.5 & $a, b$ \\
\hline 1643 & epi- $\alpha$-Cadinol (T-Cadinol) & 0.5 & $a, b$ \\
\hline 1644 & epi-a-Muurolol (syn. T-Muurolol) & 1.1 & $a, b$ \\
\hline 1648 & a-Muurolol (syn. Torreyol) & 0.4 & $a, b$ \\
\hline 1652 & $\beta$-Eudesmol & $\operatorname{tr}$ & $a, b$ \\
\hline 1657 & a-Cadinol & 1.5 & $a, b$ \\
\hline 1670 & Tetradecan-1-ol & 0.6 & $a, b$ \\
\hline 1681 & a-Bisabolol & 0.3 & $a, b$ \\
\hline 1742 & Mint sulfide & $\operatorname{tr}$ & $a, b$ \\
\hline 1762 & Benzyl benzoate & 0.1 & $a, b$ \\
\hline 1841 & Hexahydrofarnesyl acetone & 0.1 & $a, b$ \\
\hline 1876 & Hexadecan-1-ol & $\operatorname{tr}$ & $a, b$ \\
\hline 1900 & Nonadecane & $\operatorname{tr}$ & $a, b, c$ \\
\hline 2100 & Heneicosane & $\operatorname{tr}$ & $a, b, c$ \\
\hline 2300 & Tricosane & $\operatorname{tr}$ & $a, b, c$ \\
\hline 2500 & Pentacosane & $\operatorname{tr}$ & $a, b, c$ \\
\hline 2700 & Heptacosane & $\operatorname{tr}$ & $a, b, c$ \\
\hline \multirow[t]{13}{*}{2900} & Nonacosane & $\operatorname{tr}$ & $a, b, c$ \\
\hline & Total & 98.7 & \\
\hline & Terpenoids & 80.5 & \\
\hline & Hemiterpenoids & 0.4 & \\
\hline & Monoterpenoids & 22.4 & \\
\hline & Monoterpene hydrocarbons & 21.4 & \\
\hline & Oxygenated monoterpenes & 1.0 & \\
\hline & Sesquiterpenoids & 57.7 & \\
\hline & Sesquiterpene hydrocarbons & 48.7 & \\
\hline & Oxygenated sesquiterpenes & 9.0 & \\
\hline & Diterpenoids & - & \\
\hline & Non-terpenoids & 18.1 & \\
\hline & Unidentified & 0.1 & \\
\hline
\end{tabular}

Previous studies on the chemical composition of $H$. perforatum essential oil indicated high variability of the composition [15-35, 38-40]. It is dificult to compare the published results, having in mind the fact that authors analyzed the plant material from various regions, characterized by their specific enviromental and ecological factors, and in many cases phenological phase of the analyzed plant material was not given. Some authors stated different chemical compositions of $H$. perforatum essential oils depending on the plant organs examined (leaves, flowers, stems) [28, 41]. Moreover, the differences in the composition of essential oils may originate from different varieties within the same species [27], and as in most papers this taxonomic category was not given, the comparison of essential oils becomes more difficult. Generally speaking, there are $H$. perforatum essential oils with sesquiterpenoids as dominant compound class [20-21, 27, 39], but there are also oil samples where alkanes $[23,29]$ or monoterpene hydrocarbons $[33,40]$ were the major classes of compounds. Concerning the major components identified in $\mathrm{H}$. perforatum oil, most papers cited the following ones: germacrene $\mathrm{D},(E)$-caryophyllene, caryophyllene oxide, a-pinene and/or 2-methyloctane. Roughly, we can distinguish two chemotypes - two H. perforatum oil groups. The essential oils containing germacrene $\mathrm{D},(E)$-caryophyllene and caryophyllene oxide as main components [15-22, 24-25, 27] belong to the first group, while the second group includes the oils where $\alpha$-pinene and/or 2-methyloctane dominate [26-28, 30-34, 42].

Bearing in mind the above mentioned, it is interesting to compare $H$. perforatum essential oil analyzed in this study with other oils originating from Serbia. So, Šmelcerović et al. [28] identified 2-methyloctane (20.5\%), a-pinene $(13.8 \%)$, spatulenol $(9.8 \%)$ and hexadecanoic acid $(4.0 \%)$ as the main components of $H$. perforatum essential oil; this oil was characterized by a high amount of non-terpenoid compounds (44.1\%). In contrast to this, in oils of the same plant species other authors have found the following compounds as dominant: $\beta$-caryophyllene $(14.2 \%)$ and 2-methyloctane (13.1\%) [23], caryophyllene oxide [22], whereas Rančić et al. [29] identified nnonane $(63,8 \%), p$-cymene $(4.8 \%)$ and 3-methylnonane $(4.5 \%)$ as main components - which made this oil sample completely different from others in the region (and beyond). Chatzopoulou et al. [26] ascertained that aliphatic compounds $(43.83 \%)$ and sesquiterpenes $(39.73 \%)$ prevailed in their oil of $H$. perforatum while Mimica-Dukić et al. [38] found that non-terpene components such as 1-tetradecanol, 10-methyl-1-undecene and cyclodecane dominated in oils of $H$. perforatum populations collected in lowland regions, whereas sesquiterpenes were predominant in oils of the plant material collected in highland regions.

On the basis of the above presented, it can be concluded that $H$. perforatum oil analyzed in this study di-ffers from others in the region considering the main oil component - germacrene $\mathrm{D}$, but the other compo- 
nents present in a significant amount ( $\beta$-caryophyllene, 2-methyloctane and $\alpha$-pinene) make it comparable to oil samples in the region. The results found also confirm the existence of a significant variability regarding the composition of $H$. perforatum essential oil.

\section{Conclusion}

A detailed investigation of the volatile constituents of $H$. perforatum essential oil resulted in the identification of 134 components. The oil was characterized by a sesquiterepene- $(48.7 \%)$ and monoterpene hydrocarbons (21.4\%). Hypericum perforatum essential oil under study is in agreement with previous reports concerning this species. Further investigations need to be conducted in order to provide better understanding of taxonomically complex relationships among Hypericum species.

\section{Acknowledgement}

This work was financially supported by the Ministry of Education, Science, and Technological Development of the Republic of Serbia (Projects 172044 and 172047).

\section{References}

[1] S. L. Crockett, N.K.B. Robson, Taxonomy and chemotaxonomy of the genus Hypericum, Medicinal and Aromatic Plant Science and Biotechnology, 5(1) (2011) 1-13.

[2] K. Yazaki, T. Okada, in Biotechnology in Agriculture and Forestry, Y.P.S. Bajaj Ed., Springer-Verlag, Berlin, 1994, p. 167.

[3] B. Gudzic, D. Djokovic, V. Vajs, R. Palic, G. Stojanovic, Composition and antimicrobial activity of the essential oil of Hypericum maculatum Crantz., Flavour and Fragrance Journal, 17(5) (2002) 392-394.

[4] V. Saroglou, P. D. Marin, A. Rancic, M. Veljic, H. Skaltsa, Composition and antimicrobial activity of the essential oil of six Hypericum species from Serbia, Biochemical Systematics and Ecology, 35 (2007) 146-152.

[5] L. Rocha, A. Marston, O. Potterat, M. A. C. Kaplan, H. Stoeckli-Evans, K. Hostettmann, Antibacterial phloroglucinols and flavonoids from Hypericum brasiliense, Phytochemistry, 40(5) (1995) 1447-1452.

[6] A. R. Bilia, S. Gallori , F. F. Vincieri, St. John's wort and depression; Efficacy, safety and tolerability-an update, Life Sciences, 70 (2002) 3077-3096.

[7] A. Cakir, S. Kordali, H. Zengin, T. Hirata, Composition and antifungal activity of essential oils isolated from Hypericum hyssopifolium and Hypericum heterophyllum, Flavour and Fragrance Journal, 19(1) (2004) 62-68.

[8] A. Cakir, S. Kordali, H. Kilic, E. Kaya, Antifungal properties of essential oil and crude extracts of Hypericum linarioides Bosse, Biochemical Systematics and Ecology, 33 (2005) 245-256.

[9] M. Couladis, P. Baziou, P. V. Petrakis, C. Harvala, Essential oil composition of Hypericum perforatum L. growing in different locations in Greece, Flavour and Fragrance Journal, 16(3) (2001) 204-206.

[10] A. Shafaghat, Antioxidant, antimicrobial activities and fatty acid components of flower, leaf, stem and seed of Hypericum scabrum, Natural Product Communications, 6(11) (2011) 1739-1742.

[11] N. Radulović, V. Stankov-Jovanović, G. Stojanović, A. Šmelcerović, M. Spiteller, Y. Asakawa, Screening of in vitro antimicrobial and antioxidant activity of nine Hypericum species from the Balkans, Food Chemistry,103(1) (2007) $15-21$.

[12] G. Zdunić, D. Gođevac, K. Šavikin, M. Novaković, S Milosavljević, S. Petrović, Isolation and identification of phenolic compounds from Hypericum richeri Vill. and their antioxidant capacity, Natural Product Research, 25(3) (2011) 175-187.

[13] G. Laakmann, C. Schuele, T. Baghai, M. Kieser, St John's wort in mild to moderate depression: the relevance of hyperforin for the clinical efficacy, Pharmacopsychiatry, 31(1) (1998) 54-59.

[14] Z. Saddiqe, I. Naeem, A. Maimoona, A review of the antibacterial activity of Hypericum perforatum L, Journal of Ethnopharmacology, 131 (2010) 511-521.

[15] R. S. Chauhan, R. K.Vashistha, M. C. Nautiyal, A. Tava, R. Cecotti, Essential oil composition of Hypericum perforatum L. from cultivated source, Journal of Essential Oil Research, 23(3) (2011) 20-25.

[16] F. S. Sharopov, I. S. Gulmurodov, W. N. Setzer, Essential oil composition of Hypericum perforatum L. and Hypericum scabrum L. growing wild in Tajikistan, Journal of Chemical and Pharmaceutical Research, 2(6) (2010) 284-290.

[17] D. Mockute, G. Bernotiene, A. Judzentiene, The essential oils with dominant germacrene $\mathrm{D}$ of Hypericum perforatum L. growing wild in Lithuania, Journal of Essential Oil Research, 20 (2) (2008) 128-131.

[18] C. Cirak, A. Bertoli, L. Pistelli, F. Seyis, Essential oil composition and variability of Hypericum perforatum from wild populations of northern Turkey, Pharmaceutical Biology, 48(8) (2010) 906-914.

[19] A. Sevim, B. Demirci, G. Iscan, Y. B. Kose, K. H. C. Baser Composition and anticandidal activity of the essential oil of Hypericum perforatum L., Asian Journal of Chemistry, 22(2) (2010) 1315-1320.

[20] I. Schwob, J. M. Bessiere, V. Masotti, J. Viano, Changes in essential oil composition in Saint John's wort (Hypericum perforatum L.) aerial parts during its phenological cycle, Biochemical Systematics and Ecology, 32 (2004) 735-745.

[21] J. Radusiene, A. Judzentiene, G. Bernotiene, Essential oil composition and variability of Hypericum perforatumL. growing in Lithuania, Biochemical Systematics and Ecology 33 (2005) 113-124.

[22] A. Šmelcerović, N. Mimica-Dukić, S. Đorđević, Essential oil composition of Hypericum perforatum L. ssp. angustifolium from South Serbia, Journal of Essential OilBearing Plants, 7(3) (2004) 275-278.

[23] B. Gudžić, S. Đorđević, R. Palić, G. Stojanović, Essential oils of Hypericum olympicum L. and Hypericum perforatum L., Flavour and Fragrance Journal, 16(3) (2001) 201-203.

[24] D. Mockute, G. Bernotiene, A. Judzentiene, Volatile compounds of the aerial parts of wild St. John's wort (Hypericum perforatum L.) plants, Chemija 14(2) (2003) 108-111.

[25] R. Bruni, F. Pellati, M. G. Bellardi, S. Benvenuti, S. Paltrinieri, A. Bertaccini, A. Bianchi, Herbal drug quality and phytochemical composition of Hypericum perforatum L. affected by ash yellows phytoplasma infection, Journal of Agricultural and Food Chemistry, 53(4) (2005) 964-968. 
[26] P. Chatzopoulou, T. Marković, D. Radanović, T. V. Koutsos, S. T. Katsiotis, Essential oil composition of Serbian Hypericum perforatum local population cultivated in different ecological conditions, Journal of Essential OilBearing Plants, 12(6) (2009) 666-673.

[27] F. Maggi, C. Cecchini, A. Cresci, M. M. Coman, B. Tirillini, G. Sagratini, F. Papa, S. Vittori, Chemical composition and antimicrobial activity of the essential oils from several Hypericum taxa (Guttiferae) growing in central Italy (Appennino Umbro-Marchigiano), Chemistry \& Biodiversity, 7 (2010) 447-466.

[28] A. Šmelcerović, M. Spiteller, A. P. Ligon, Ž. Šmelcerović, N. Raabe, Essential oil composition of Hypericum L. species from southeastern Serbia and their chemotaxonomy, Biochemical Systematics and Ecology, 35 (2007) 99-113.

[29] A. Rančić, M. Soković, J. Vukojević, A. Simić, P. Marin, S. Duletić-Laušević, D. Djoković, Chemical composition and antimicrobial activities of essential oils of Myrrhis odorata (L.) Scop, Hypericum perforatum L. and Helichrysum arenarium (L.) Moench., Journal of Essential Oil Research 17(3) (2005) 341-345.

[30] M. Pavlović, O. Tzakou, P. V. Petrakis, M. Couladis, The essential oil of Hypericum perforatum L., Hypericum tetrapterum Fries and Hypericum olympicum L. growing in Greece, Flavour and Fragrance Journal 21(1) (2006) 84-87.

[31] G. Pintore, M. Chessa, G. P. Boatto, R. Cerri, M. Usai, B. Tirillini, Essential oil composition of Hypericum perforatum L. var. angustifolium DC growing wild in Sardinia (Italy), Journal of Essential Oil Research, 17(5) (2005) 533-535.

[32] S. Erken, H. Malyer, F. Demirci, B. Demirci, K. H. C. Baser, Chemical investigations on some Hypericum species growing in Turkey-I, Chemistry of Natural Compounds, 37(5) (2001) 434-438.

[33] A. Cakir, M. E. Duru, M. Harmandar, R. Ciriminna, S. Passannanti, F. Piozzi, Comparison of the volatile oils of Hypericum scabrum L. and Hypericum perforatum L. from Turkey, Flavour and Fragrance Journal, 12(4) (1997) 285-287.

[34] E. Osinska, Comparative study on essential oil content and its composition of different ecotypes of St. Johns wort (Hypericum perforatum L.), Herba Polonica, 48(4) ( 2002) 174-177.

[35] K. H. C. Baser, T. Ozek, H. R. Nuriddinov, A. B. Demirci, Essential oils of two Hypericum species from Uzbekistan, Chemistry of Natural Compounds 38(1) (2002) 54-57.

[36] H. Van den Dool, P.D. Kratz, A generalization of the retention index system including linear temperature programmed gas-liquid partition chromatography. Journal of Chromatography A, 11 (1963) 463-471.

[37] R. P. Adams, Identification of essential oil components by gas chromatography/mass spectrometry, Allured Publishing Corp., Carol Stream, Illinois, 2007.

[38] N. Mimica-Dukić, I. Ivančev-Tumbas, R. Igić, M. Popović, O. Gašić, The content and composition of essential oil of Hypericum perforatum from Serbia, Pharmaceutical and Pharmacological Letters, 8(1) (1997) 26-28.

[39] I. Schwob, J. M. Bessiere, J. Viano, Composition of the essential oils of Hypericum perforatum L. from southeastern France, Comptes Rendus Biologies, 325(7) (2002) 781-785.

[40] P. Weyerstahl, U. Splittgerber, H. Marschall, V. K. Kaul, Constituents of the leaf essential oil of Hypericum perforatum L. from India, Flavour and Fragrance Journal, 10(6) (1995) 365-370.

[41] A. M. Kakhky, A. Rustaiyan, S. Masoudi, M. TabatabaeiAnaraki, J. Aboly, Chemical composition of the essential oils from flowers, leaves, stems and roots of Hypericum perforatum L. from Iran, Journal of Essential Oil-Bearing Plants 11(5) (2008) 548-552.

[42] P. V. Petrakis, M. Couladis, V. Roussis, A method for detecting the biosystematics significance of the essential oil composition: The case of five Hellenic Hypericum L. species, Biochemical Systematics and Ecology 33 (2005) 873-898.

Izvod

\section{HEMIJSKI SASTAV ETARSKOG ULJA BILJNE VRSTE Hypericum perforatum $\mathrm{L}$.}

Aleksandra S. Đorđević

(ORIGINALNI NAUČNI RAD) UDK 66

Departman za hemiju, Prirodno-matematički fakultet, Univerzitet u Nišu, Niš, Srbija

Etarsko ulje izolovano iz svežih nadzemnih delova biljne vrste Hypericum perforatum $\mathrm{L}$. analizirano je metodama gasne hromatografije (GC) i kombinacijom gasne hromatografije i masene spektrometrije (GC/MS). Identifikovano je 134 komponenti, koje čine $98,7 \%$ ukupnog sastava ulja. Glavne komponente ulja $H$. perforatum bile su: germakren $D(18,6 \%),(E)$-kariofilen $(11,2 \%)$, 2-metil-oktan $(9,5 \%)$, a-pinen $(6,5 \%)$, biciklogermakren $(5,0 \%)$ i $(E)-\beta$-ocimen $(4,6 \%)$. Ispitivano ulje $H$. perforatum bilo je okarakterisano velikom količinom seskviterpenoida $(57,7 \%)$, naročito seskviterpenskim ugljovodonicima (48,7\%). Monoterpenoide su takođe mahom činili ugljovodonici $(21,4 \%)$. Količina ne-terpenoidnih jedinjenja iznosila je 18,1\% ukupnog ulja.
Ključne riječi: Hypericum perforatum, Hypericaceae, sastav etarskog ulja. 